\title{
Renewable Energy in Malaysia: Strategies and Development
}

Syed Shah Alam (Corresponding authors)

Faculty of Economics and Management, Universiti Kebangsaan Malaysia

43600 UKM Bangi, Selangor, Malaysia

E-mail: shahalam@ukm.my

Nor Asiah Omar

Faculty of Economics and Management, Universiti Kebangsaan Malaysia 43600 UKM Bangi, Selangor, Malaysia

E-mail: norasiah@ukm.my

Mhd. Suhaimi Bin Ahmad

Faculty of Economics and Management, Universiti Kebangsaan Malaysia 43600 UKM Bangi, Selangor, Malaysia

E-mail: mhsuh@ukm.my

H.R. Siddiquei

Department of Electrical and Computer Engineering, Faculty of Engineering International Islamic University, Malaysia

E-mail: engg_hasin96@yahoo.com

Sallehuddin Mohd. Nor

Faculty of Economics and Management, Universiti Kebangsaan Malaysia 43600 UKM Bangi, Selangor, Malaysia

E-mail: mhsuh@ukm.my

Received: December 13, 2012

doi:10.5296/emsd.v2i1.3197
Accepted: January 3, 2013

URL: http://dx.doi.org/10.5296/emsd.v2i1.3197 


\section{MInstitute ${ }^{\text {Macrothink }}$}

\section{Abstract}

The field of renewable energy (RE) has been widely growing topic of fascination by researchers, industrialist and the public alike. This study tried to highlight the development of renewable energy usage in Malaysia as well as the world. In this paper, initiatives taken by the private and government schemes to nurture the development of sustainable energy in Malaysia are addressed. Malaysia is well rich within its huge potential of the use of sustainable natural resources due to an extremely moderate climate around the year. Only a minor adaptation and mitigation strategies need to be taken to push a popular and effective use of safe and renewable energy. It is necessary to develop proper plan by the local government as well as the central government of Malaysia for the sustainable development of renewable energy in Malaysia. The issues highlighted in this study is expected to garner a better understanding of how the topic of renewable energy can be better reflected as a growing and strengthening filed of research.

Keywords: Alternative energy, Malaysia, Impact of energy usage, Sustainable Development.

\section{Introduction}

Malaysia which is located between $1^{\circ}$ and $7^{\circ}$ North of the Equator, has all these renewable energy resources in abundance, but most of these energy resources are yet to be exploited. Malaysia has a steady GDP growth of $4.6 \%$ in 2011 which is rare among the ASEAN countries (Trading Economics, 2011). In comparison with the fast economic development, its final energy consumption is also growing in a meteoric rate. It is observed that the growth rate of energy consumption in between 2000 to 2005 was 5.6\% and reached 38.9 M.toe in 2005 (Saidur et al., 2009). The final energy consumption is expected to reach to 98.7 Metric tons in the year of 2030, which will be nearly three times than the 2002 level (Najib, 2009).

Experts hypothecated that the reservation of natural gas will be finished in 70 years in Malaysia. It also expected that oil is to be used up at current usage rate for about 16 years (Shigeoka, 2010). Therefore awareness in the matter of energy security and change of climate are leading the Malaysian Government to take significant changes in their energy policy.

The basic structure of Malaysian economic and productive development is based on the consumption of fossil fuel as it is the world wide scenario. The dependency of fossil fuel for the energy production ultimately emits huge green house gases (GHG), mainly $\mathrm{CO}_{2}$. Such GHG emission creates serious consequences as climate change and rise of see level which implicitly helps to several devastating impacts that affects human lives as well as ecological balance of the entire planet. In addition to that the intensity of energy usage, the energy wastes (in particular nuclear waste), the secondary effects (like pollution) and the provision from fossil fuel (like geopolitical crisis) highlights the question on the pressing needs to change the dominant energetic model (Lucia and Debora, 2010). Therefore, significant reductions in greenhouse gas emissions are preciously needed to reduce the adverse effects of changing climate. Renewable energy could be the alternative source for the energy production. These renewable energy technologies includes, water (hydroelectric and marine 
energy), solar (thermo and photovoltaic), wind (single turbine or wind field), geothermic sources and biomass (Lucia and Debora, 2010).

In Malaysia, application of the green technology is considered as one of the important solutions which are being followed by many countries all over the world to identify the issues of energy and environment gradually (Islam et al., 2009). But scientific technology and suitability of RE resources will not help the government to implement successful use of RE sources allover Malaysia, unless it can significantly draw the public opinion towards the use of RE. Therefore, the application of RE technologies is more efficient to rely on local drivers as for example increase in the employment, income and improved regional economies (Domac et al., 2005). The successful development and dissemination of RE technologies depends on their perfection of the isolate rural communities: providing energy, with the maintenance of a minimum level of income (Bush, 2006). Moreover, RE technology suffers from different kinds of problems: high costs and long terms, social resistance to the energetic transition, factors influencing socio-political and community acceptance, difficulty of energy industries to produce and use renewable energy from existing energy infrastructures.

There are some technologies that require a lot of involvements, influence and grant by the users, as for example small-scale solar energy system and energy efficiency investments.

The issues of struggles are costs and user expectations about the quality. Other technologies namely wind and biomass need to maintain their relations with local residents and to help the local economy and social structure (Brohmann, 2007). Therefore, in order to reduce the generation of green gasses to ensure safer environment for our next generations, it is required to encourage the research for financial support and to establish a specific policy depending on available alternative RE resources and their local acceptance. It is also required to change style of life re-building on the concept of new technology, which goes beyond the materiality, and society. To date, a few significant researches are carried out on the assessing attitude towards RE uses in Malaysia. It is important to introduce appropriate RE projects in appropriate contexts in Malaysia and there should be a wide consideration of the political and policy, socio-economic, Malaysian cultural and its geographic conditions (Brohmann, 2007).

This paper reviews and analyzes the current and potential climate change challenges and environmental concerns related with energy systems: the status and challenges of energy accessibility and energy security; the acceptability of Malaysian rural and urban people towards the use of available renewable resources and their predicted contribution to Malaysian economy then follow. The advancement of renewable energy technologies under private and government schemes that boost sustainable energy development in Malaysia also are addressed.

\section{Climate Change and Climate Impacts}

In 1990s, political actions, including the global level strategies to encourage the use of RE, where recommended by the scientific community to fight against climate change at the national and local levels. 


\section{Mll Macrothink}

The creation of the Global Environment Facility (GEF), and the United Nations Framework Convention on Climate Change (UNFCCC, as a global framework) by the World Bank, UNEP and UNDP in 1991 was among the strategies (GEF, 2007; Lorraine, 2004). GEF had had given its main priority for the expression of climate change "mitigation" and "adaptation" strategies. In 1994, the UNFCCC had achieved its full phased operation, and after the negotiations for about two and a half years of international the Kyoto Protocol had been built. This protocol based on the incorporated features for the future cut down of CO2 emissions within the international area .Conversely, some nations withdrawn their cooperation from this protocol during the time for its ratification, among them USA was the most notable one.

At Global Climate Coalition (GCC), strong lobby efforts against ratification were formed against the protocol (Norma and Michael, 2004). Besides USA, many nations have ratified the protocol including the EU as a whole. In order to achieve the targets, mechanisms that are market-based were proposed to help Annex I parties fulfill their goals. With legally binding targets and an agreement the Protocol entered into force in 2005.And 5.2\% overall reduction was the target of emissions for 2008-2012. According to the agreement, the EU undertook a target of reducing its emissions by $8 \%$ (UNDP, 2004).

Nowadays, people all over the world are concerned about energy security and independence in national policy. This is because of the reduction of carbon emissions regarding environmental and health benefits (Bush, 2006). There are some successful experiences of renewable energy technologies regarding of the development and diffusion, whereas similar projects have become adverse with others (Brohmann et al., 2007). Therefore, it has become an important issue to discover the limitations and barriers for successful amplification of RE into cities and rural areas of individual country along with its geographical cortex and natural resources. The analysis of the amount of improvements is also required to adopt RE policy so that it meets the needs of local, social and environmental change. In the next sections, the RE resources and the geo-political situations of different countries in different regions are discussed together with their taken stapes towards embolden the use of RE.

\section{Environmental Impacts from Energy Systems}

Malaysia must adopt RE sources such as sunlight, wind, and biomass in order to combat global warming and the other problems associated with fossil fuels. However, all renewable energy technologies are not applicable to all applications or locations. There are some environmental related matters need to be considered during conventional energy production. Some of the key environmental impacts associated with renewable technologies and suggests appropriate responses to them are represented by this paper. The Union of Concerned Scientists along with the three other national organizations, America's Energy Choices, survey that the RE sources can supply more than half of the US energy supply by the year 2030 maintaining the environmental standards.

\subsection{Wind Energy}


It is very difficult to imagine an energy source more benign to the environment than wind power. The advantages of wind energy are; it doesn't produce any air or water pollution that involves toxic or hazardous substances, and doesn't threat the public safety. However, people are against to have wind industry because of the visibility and noise of wind turbines, and their impacts on wilderness areas.

Another misconception about wind power is its land usage. Many researchers assumed that wind turbines must be sited into a certain distance considering all the used land in between. This misunderstanding leads to a error in estimating required land area for producing a huge amount of wind power. It was surveyed in 1970s that required area for locating turbines is 18,000 square miles. However, the wind turbines cover only a small portion of this land area. Where the remaining areas can be used for other uses or left as its natural state. Nowadays, development of wind power takes place in farming areas. Farmers grow plants right up to the base of turbine towers in Europe, while in California cows can be seen grazing in their shadow. By giving lease the land for wind turbines, the landowners can earn more than the usual.

Development of wind power may cause fatal conflicts on land usage. Except in areas where heavy logging has already occurred, cutting the forest trees leads to generate controversy. Moreover, in the populated areas, people strongly oppose to wind power regarding them as unsightly and noisy as well as a fear of reducing the property values for the presence of wind power.

Electrocution or collisions with spinning rotors is causing bird death that have become a problem at the Altamont Pass wind "farm" of California. For a three-year period more than 30 golden eagles were threatened in California and 75 other raptors were injured or died. Researchers are trying to find the cause of these deaths and determine preventive measures that influence the public image and wind industry growth rate. Proper areas with proper imagination, careful planning and connections with the other wind industry, environmental groups should be considered.

\subsection{Solar Energy}

Operation of solar power systems does not produce any air pollution. Therefore, only health, environmental and safety issues need to be considered during manufacturing, installation and finally disposing off. To manufacture this, energy is required and the usage of fossil fuels will produce emissions. The energy balance is generally favorable to solar systems. Some research found that water heaters based on solar energy increase the amount of hot water generation per unit of fossil energy.

There are some materials used in solar systems cause health problems and safely issues for the workers as well as the people coming into contact with him. For example, the production of photovoltaic cells sometimes requires hazardous materials like arsenic and cadmium. Moreover, Silicon used in solar cells can be dangerous to workers if they breathed in as dust. Workers during the production of photovoltaic modules and components must take proper caution for exposure to these materials. Another danger that disturbs fumes comes from 


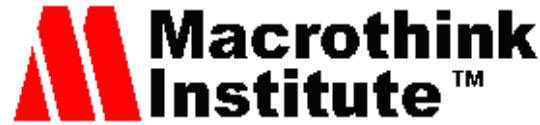

photovoltaic modules is also very dangerous. It may result in burning homes or buildings injuring fire fighters.

There is no difference of potential hazards with the innumerable hazards that people experience regularly in an industrial society. By taking proper precaution, the dangers can be minimized to it its least.

An additional problem is creating with the utility-scale solar power plants that require one square kilometer for every 20-60 megawatts (MW) generation but keeping wildlife in a risk. However, this problem is not the mere problem to solar power plants. Coal based electricity generation requires the land per unit of energy delivered considering the land is used for strip mining. Requirement of cooling water in solar-thermal plants makes it expensive in desert areas.

There is not the only way to generate electricity from sunlight. It can be generated from large central power plants. The unused space of the roofs of homes and buildings can be used in the form power plant. In addition to that, to design a solar building plant the structure itself acts as the collector, so the additional space is not required at all.

\subsection{Biomass}

To produce biomass power from the burning of plant raises fatal environmental issues. Moreover, air pollution occurs during combustion of biomass and biomass-derived fuels production; besides this, there is a matter that concerns the effect cultivating energy crops. The impacts depend on the policies of resource management. It is very complicated because there is no single biomass technology and many production and conversion methods and each of these has different environmental impacts. Malaysia has several types of biomass. Figure 1 shows the types of biomass in Malaysia. Proper management of these biomass can bring a better future in renewable in Malaysia.

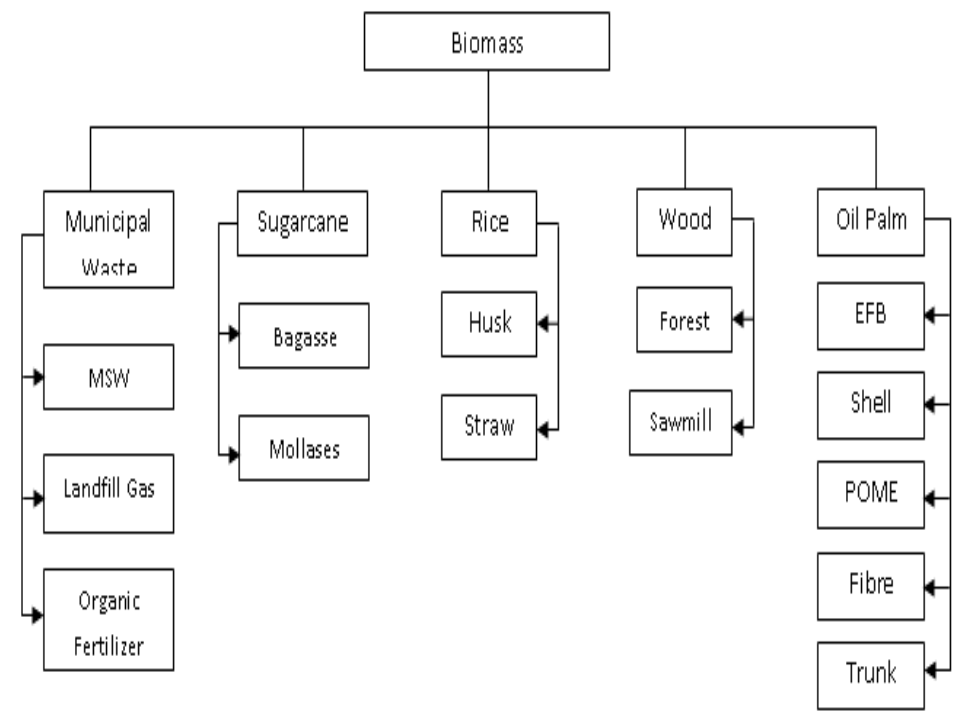

Figure 1. Types of Biomass in Malaysia 


\subsection{Air Pollution}

Combustion of biomass pollutes the air and generates carbon monoxide, nitrogen oxides and particulates. Based on the technology used, amount of pollution caused per unit energy can be determined. For example, wood-burning stoves and fireplaces produce more pollutant than others. Nowadays, specialized pollution control devices are available worldwide such as electrostatic precipitators. However, it is doubtful to use without specific regulation of enforcement. The conventional biomass-fueled power plants and the coal-fired power plants cause emissions and these are similar in manner. However, one noticeable difference that combustion of biomass produce very little sulfur dioxide. Particulates emissions is the most serious problem of these two combustions and this can only be controlled by special devices.

Modern technologies including whole-tree burner and gasifier produce lower emission than the natural gas fueled power plants. Burning system of raw municipal waste generates harmful emissions which is unique in nature. Recently, most of the energy plants are likely to use refuse-derived fuel (RDF) as it is the most cost-effective way to reduce emission.

If the conventional gasoline is replaced by the biomass-derived methanol and ethanol as vehicle fuels, some types of pollutions caused from automobiles can be reduced greatly. Gasoline evaporates faster than methanol and ethanol and this helps in reducing evaporative emissions of volatile organic compounds (VOCs). Reacting with heat and sunlight, it generates ground-level ozone. Environmental Protection Agency estimated that use of pure methanol or ethanol can reduce 85 to 95 percent from the tailpipe of the VOC emissions.

\subsection{Greenhouse Gases}

If biomass is substituted for fossil fuels in a sustainable manner, emissions of greenhouse gases would reduce greatly. Carbon dioxide is released on the air while burning the biomass. The amount of carbon dioxide released is the same as required to replace the plans grown for producing biomass. Therefore, no net emissions of carbon dioxide would remain in a sustainable fuel cycle, although inputs of some fossil-fuel might be required for several purposes such as planting, harvesting, transporting and processing biomass. If efficient cultivation and conversion processes are used, emission rate can be reduced. Furthermore, if the RE sources supply the energy needed to produce and process biomass, resulting global warming becomes zero. Furthermore, few or no net greenhouse emissions causes by the crop residues or municipal solid waste. Moreover, if landfill wastes are not burned and green house gas methane is released through anaerobic decay, greenhouse can be benefitted in some cases.

\subsection{Implications for Agriculture and Forestry}

Growing trees and plans for producing energy cause improvement in soil quality as well as farm economics. During off-seasons, farmers can grow energy crops to generate a steady supplemental income or they can grow these crops in unused land. Stabilization of cropland to erosion and flooding can be done by the energy crops. If these crops are grown for several years before harvesting, soil can be stabilized by their roots and leaf. These crops can be planted or self-regenerated and their varieties can reduce the necessity for disruptive tilling and planting. For example is swithgrass that causes soil losses, but this can be ignored 
compared to corn. However, improper management of energy farming might have harmful effect on environment. Less pesticide and fertilizer are required to grow energy crops in comparison to conventional food crops. However, energy firming in large scale increases chemical usage and more land remain uncultivated. It has also impact on biodiversity by the devastation of species habitats; especially more intensively managed forests are more vulnerable to energy harvesting. It is also required to leave enough wastes behind, otherwise, usage of agricultural or forestry wastes and residues as fuel could deplete the soils of organic content and nutrients.

Energy farming raises low-interest sustainable agriculture. New federal effort is required for farming of food crop rotation and integrated pest management. Sound oil is also required to improve long-term productivity. Natural fertilizer can be provided by the nitrogen-fixing crops. Moreover, usage of pesticide can be reduced through crop diversity. Harvesting more forest wood for energy has two-sided effect on environment. Firstly, it provides incentive for efficient management of resources of the forest-product industry and as a result, forest health is being improved. Conversely, it provides excuse to exploit forests in an unsustainable manner. Unfortunately, the man made forests for commercial purposes are not managed properly and many people notify it as the destruction of forest. Peoples' concern can be met by proper government policy on forestry and following the principle strictly. Application of such principle may help to extract energy from forests.

\subsection{Hydropower}

Hydroelectricity is a well-established technology, and the first renewable technology to be developed. It is already a major contributor to world energy supplies, producing power reliably and at competitive prices for about a century. The major advantages of hydropower include renewable, production of negligible amount of greenhouse gases, cost-effective way of storing electricity and adjustable to provides the electricity needed by the consumers. It provides $17 \%$ of global generation capacity and $20 \%$ of energy produced annually (Othman, 2005).

Gas emission caused by the fossil fuel combustion is eliminated by the hydroelectricity as well as the pollutants such as sulfur dioxide, nitric oxide, carbon monoxide, dust and mercury in the coal. The hazards of coal mining and nuclear waste can be avoided by the hydroelectricity. Moreover, it is immune from the dangers associated with the uranium mining. Load factor of hydroelectricity power plant is more predictable in comparison to wind farms. It can be generated whenever necessary. Based on the power demand, the hydroelectric plants can be regulated.

The mini-hydro potential of Malaysia was assessed and viable sites were identified (K. Sopian et. al., 2005). Under the rural electrification programme, some of these sites were implemented with government funding based on run-of the -river systems ranging from 500 $\mathrm{kW}$ to $1000 \mathrm{~kW}$ capacity. Currently there are thirty nine units with total capacity of 16.185 MW in Peninsular Malaysia, seven units of total capacity of 2.35 MW in Sabah and five units of total capacity $5 \mathrm{MW}$ in Sarawak. There is substantial experience in building, operating and maintaining mini-hydro plants. It is expected that similar plants can be built as and when 


\section{Macrothink}

required Mini-hydro is a mature technology based on proven equipment. The area of $\mathrm{R}$ and $\mathrm{D}$ is the creation and dynamic use of detailed hydrodynamic and computer models. It is a hope that, the models can be used to predict and forestall problems caused by extremes conditions of weather or power demands.

\section{Energy Accessibility and Energy Security}

Reservation of proven oil is 4.2 billion barrels in Malaysia and the reference simulation is dependent of this. Its amount is has declined by $8.7 \%$ in between 2003 and 2006. Now-a-days, Petronas is trying to discover proven oil in deepwater zones, however, the reserves are diminishing with continuous production. To conserve Malaysia's oil resources, government introduced the National Depletion Policy in 1980. The amount of maximum oil production is 650,000 barrels daily (excl. NGL and condensate). Crude oil production depends on the availability of reserve capacity. After certain time, it is supposed to decline for keeping the depletion rate fixed at 3\%. Malaysia reserved 2.48 trillion cubic meters of proven natural gas in 2006. With the increase of energy demand, production of natural gas production has increased to 16.5 million cubic meters daily, up to $16.9 \%$ since 2003. Limitation of resources is also experienced by the production of natural gas.

If the production increases by 3.5\% annually as long as the reserves production ratio is $20: 1$, it would reach to $5 \%$ per year. One good thing about Malaysia's reservation is that it is kept constant at a level of 15.6 billion barrels of oil equivalent. Therefore, gas production will be raised at a constant rate of 3.5\% (Mitchell and Schmidt, 2008). Figure 1 shows the Malaysian energy demand-supply balance.

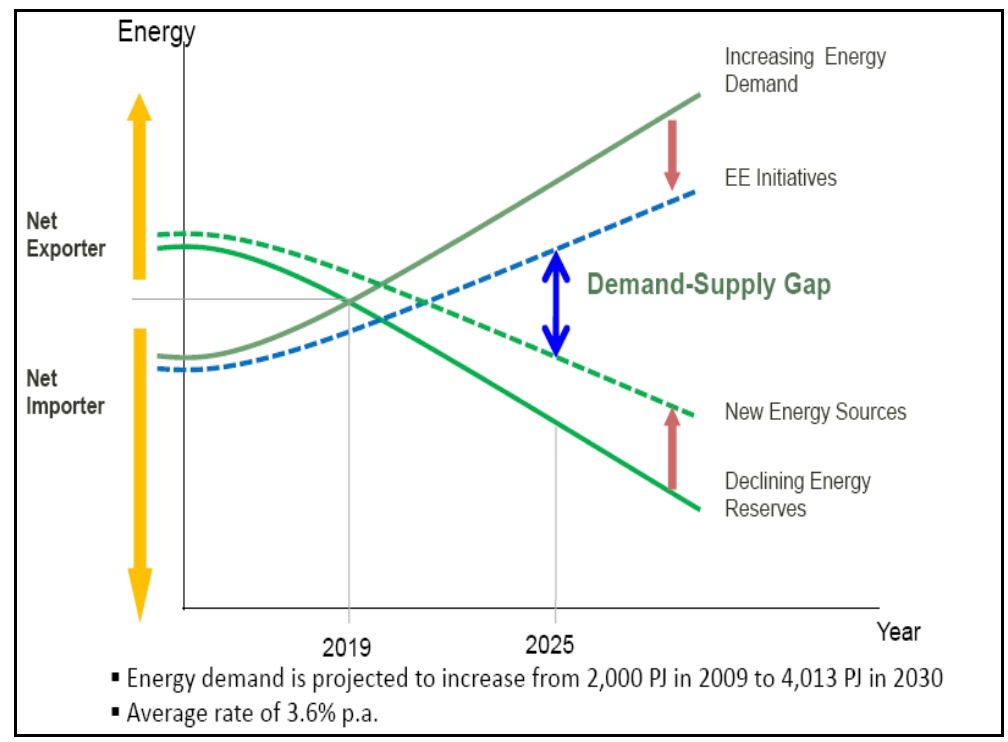

Figure 2. Energy demand-supply balance

Net energy consumption is targeted to rise by $1 \%$ compared to growth rate of the non-hydrocarbon economy. According to the (Lucia and Debra, 2010) Fuel Diversification Strategy, it is said that the energy mix is generated by natural gas, coal, oil and alternative energy. Asia Pacific Energy Research Centre found that natural gas demand is subjected to 


\section{Macrothink}

rise by $3.1 \%$, coal demand $22.3 \%$ and oil demand by $2.4 \%$ in the first four years. Throughout the following ten years natural gas and oil consumption raised by $2.8 \%$ and coal consumption by $5.9 \%$ and thereafter natural gas and oil consumption is projected to rise by $2.7 \%$ and coal by $4.2 \%$. Demand of alternative energy for domestic uses is determined by the overall primary energy requirements as well as the capacity to fulfill these requirements by the rest of four energy resources (Mitchell and Schmidt, 2008).

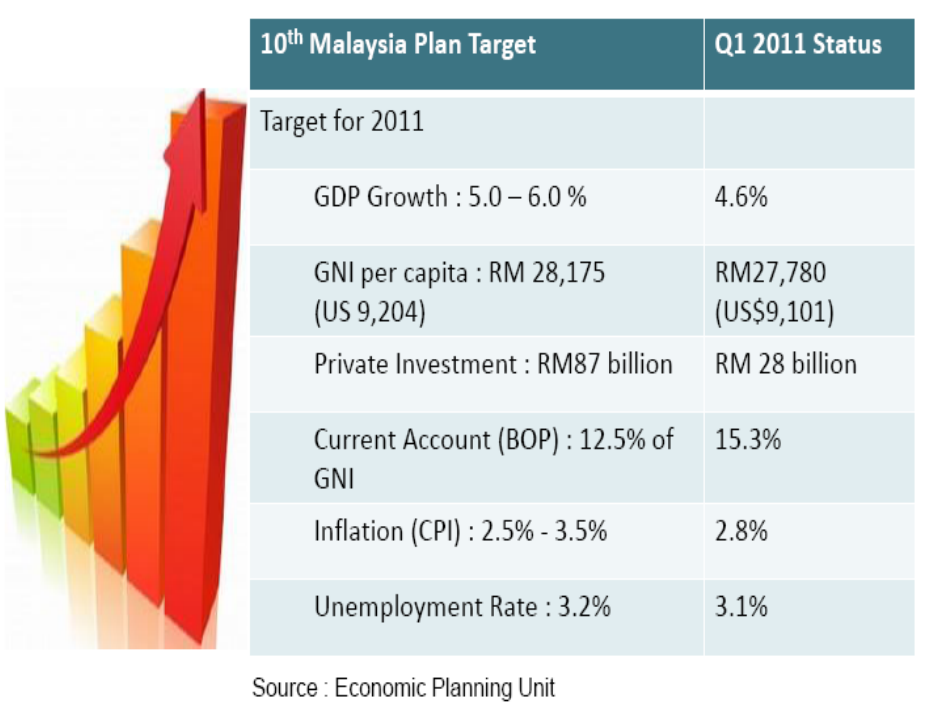

Figure 3. Economic Performance of Malaysia

Oil production in Malaysia is already in steady state condition and is going to decline soon. Therefore, there is possibility of becoming an oil importer in 2011 and gas importer in 2018. It may cost RM 40 billion per year and this may increase the fiscal deficit of Malaysia (Mitchell and Schmidt, 2008).

\section{Application and Potential for Sustainable Energy Development}

In addition to the national depletion policy mentioned above, there are some strategies of varying detail to encourage the diversification of fuel type and sources. According to the 9th Five Year Plan (2005-10), new electricity generating plants in peninsular Malaysia will be supplied by coal (Mitchell and Schmidt, 2008). The Ninth Plan defined RE as the "fifth fuel" to fulfill the objectives of diversification, energy security and sustainability. Over half of the world's palm oil is produced in Malaysia. Moreover, $60 \%$ of world palm oil is exported by this country. Recently, surplus of palm oil caused decreased the world prices. The palm oil export of Malaysia in 2006 was 14 m tons. In that year, its crude oil export was about one thirds of its palm oil exports. Its gas and palm oil export values are in same order of magnitude. 


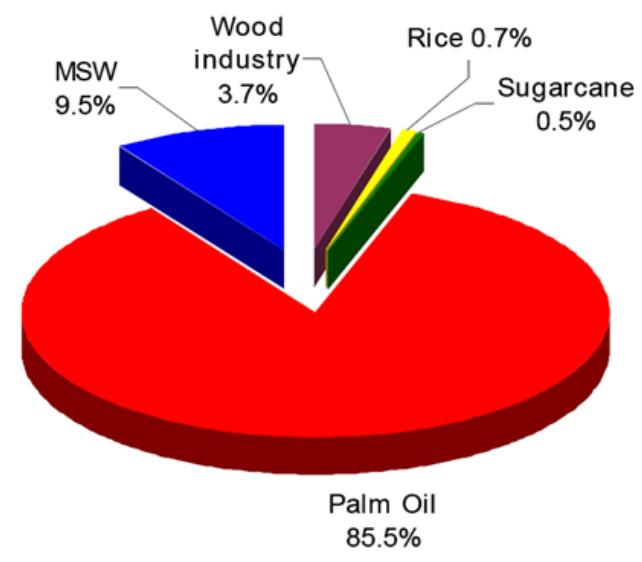

Figure 4. Total Production of Bio-Mass in Malaysia

The top prospect in Malaysia is the use of palm oil as fuel to bring energy security. Among the total biomass produce in Malaysia, palm oil is having the largest percentage $(85.5 \%$ is shown in figure 3). Use of latest technology and advance research, palm oil is already being used as bio- fuel. The bio-fuel strategy is about to develop B5 ("ENVO") diesel which is a blend of 5\% processed palm oil and 95\% petroleum diesel. This B5 fuel can be used for transport and industrial purpose in Malaysia. For the development of B5, there requires a programme for technical development (of the palm oil component), testing and acceptance by engine manufactures of the blended product, and the development of a supply infrastructure in Malaysia. Though the Government agencies started using B5 since February 2009, the B5 program was implemented in Central Region of Peninsular Malaysia by 1st November 2011. By this time, under Green Technology Financing Scheme (GTFS), RM 1.5 billion incentives were dedicated for 10MP. In addition to that, under the Clean Development Mechanism, biomass, biogas and landfill projects were included as well as the certified emission reduction issued to 10 companies totaling to 1,231,655 tonnes of $\mathrm{CO}_{2}$ equivalent. Table 1 shows the potential power generation from palm oil residues at Palm Oil Mills in Malaysia.

Table 1. Potential Power Generation using Palm Oil

\begin{tabular}{|c|c|c|c|c|c|c|}
\hline $\begin{array}{l}\text { Type of } \\
\text { Industry }\end{array}$ & $\begin{array}{l}\text { Production } \\
\text { (Thousand } \\
\text { Tonne) }\end{array}$ & Residue & $\begin{array}{l}\text { Residue } \\
\text { product } \\
\text { Ratio } \\
(\%)\end{array}$ & $\begin{array}{l}\text { Residue } \\
\text { Generated } \\
\text { (Thousand } \\
\text { Tonne) }\end{array}$ & $\begin{array}{l}\text { Potential } \\
\text { Energy } \\
\text { PJ }\end{array}$ & $\begin{array}{l}\text { Potential } \\
\text { Electricity } \\
\text { Generation } \\
\text { (MW) }\end{array}$ \\
\hline \multirow[t]{5}{*}{ Oil palm } & 59800 & $\begin{array}{l}\text { EFB at } \\
65 \% \mathrm{MC}\end{array}$ & 21.14 & 12641 & 57 & 521 \\
\hline & & Fiber & 12.72 & 7607 & 108 & 1032 \\
\hline & & Shell & 5.67 & 3390 & 55 & 545 \\
\hline & \multicolumn{2}{|l|}{ Total Solid } & & 16670 & 220 & 2098 \\
\hline & \multicolumn{2}{|c|}{$\begin{array}{l}\text { POME }\left(3.5 \mathrm{~m}^{3} \text { per ton of } \mathrm{CPO}\right. \\
165 \% \text { of } \mathrm{FFB})\end{array}$} & & 38870 & & 320 \\
\hline
\end{tabular}

Ref - Malaysian Oil Palm Statistics 2002, 22"ne Edtion, MPOB Data is for the year 2002. 


\section{Ml Macrothink}

The Ninth Plan assumes to replace 10,000 billion dollar of oil in the domestic diesel market. Therefore, palm oil exports could be changed over food to fuel market internationally. If the palm oil prices become relatively low, the demand of it will increase in importing countries such as EU. At the expense of palm oil exports, it will be possible to achieve 200-300,000 billion dollar and more. As a consequence, there would be insignificant effect on the world oil market and overwhelming effect on the world palm oil market. Therefore, the policy preferences might not be sustainable for the fuel market. As the world's leading supplier of palm oil, Malaysia is in a very fortunate position. It will be benefitted, if the palm oil prices increase because of the variation of supply from food to fuel consumption.

\section{Malaysian Energy Policy}

The National Energy Policy of Malaysia was introduced in 1979. There are three main objectives of this policy. The first objective is aimed at ensuring an adequate, secure and cost-effective energy supply based on the maximum use of indigenous resources. The second objective is the utilization objective that deals with the promotion of efficiency and conservation measures as a way to eliminate wasteful and non-productive patterns of energy consumption. The third and final objective is the environment objective which states that in achieving the supply and utilization objectives, environmental concerns will not be neglected (Wright, 2008). The Malaysian Government has taken several steps to explore and promote the use of renewable energy as an alternative fuel source. These steps include the Fifth-Fuel Policy under the 8th and 9th Malaysia Plan, Energy Efficiency in Commercial Buildings (MS1525), The Kyoto Protocol, the Malaysian Building Integrated Photovoltaic Programme (MBIPV), and Biomass (Haw et al., 2006). Most of the major power stations in Malaysia are still using fossil fuels, such as oil, gas and coal to generate electricity, despite having endowed with abundance of natural resources for renewable energy exploitation.

The largest electricity utility company in Malaysia is Tenaga Nasional Berhad (TNB) having the largest generation capacity of 10,481 MW (Haw et al., 2006). At the end of 2005, the Fifth-Fuel Policy of the 8th Malaysia Plan, targeted for 500MW of electricity generation from renewable sources to the national grid. Only 12MW was delivered from two projects from the Small Renewable Energy Power Programme (SREP). The wide gap between policy and implementation clearly proves that there are barriers to the effective transition from conventional to a sustainable energy development (Kementerian Tenaga Air dan Komunikasi, 2005). Being failure to reach the target, the government has proposed the Fifth- Fuel Policy to be continued into the 9th Malaysia Plan from 2006 to 2010. The government again recommended to promote and to give further impetus towards the development of a more sustainable energy sector in the country. One of the proposed recommendations is the Energy Efficiency in Commercial Buildings or known as MS1525.

\subsection{Relevance of Effective Strategies}

Hydrocarbon is currently considered as a source of government revenue as well as a source of energy in Malaysia. For this analysis, simulations were carried out first. All scenarios were constructed in such a way that structural economic reforms do not significantly alter the present propensity of the non-hydrocarbon sector to generate government revenue, attract 
government expenditure, and generate imports and exports. In order to identify very simple assumptions for how long the current dependencies could be sustained, projections for the growth of the non-hydrocarbon economy were combined with various reserve and production profiles, and various hydrocarbon prices. The size of the fiscal adjustment and of hydrocarbon imports was also determined. Secondly, it was needed to verify that how far these adjustments were feasible or likely in the time required. The scenarios usually use simplified assumptions that were deducted from historical data, country authorities and other sources such as the World Bank, APEC, UNCTAD, and IMF. This analysis is used to illustrate a general tendency. Extrapolation into the distant future gives an idea about how trends extend, rather than results for particular years.

\subsection{Small Renewables Programme}

Renewable Energy Programme (SREP) was first launched in May 2001, with the coordinating and oversight Special Commission on Renewable Energy (SCORE) also established at that time. Under the 21-year agreements of SREP, it is allowed to sell 10 MW output to the utility. On the basis of “willing seller and willing buyer”, any renewable energy plant can apply to sell energy to the grid. The first renewable energy purchasing agreement (REPA) between TNB and a plant owner was signed in 2001. However, the program is limited to $219 \mathrm{MW}$ in 2011 and expected to increase to nearly one GW in 2015. The bulk of the generating capacity to be installed is set aside for biomass and mini-hydropower. The participation has already increased and the obtained results are quite encouraging.

\subsection{Issues with Renewables}

Currently, the main focus of the Malaysian energy providers is to meet the rising short- and medium-term demand. The small scale development of RE projects causes decrease in natural gas and as a result, it enforces to use more coal to meet their immediate needs. Palm oil, the most potential renewable energy source in Malaysia is proven problematic these days. The conversion of over one million of forest land into palm oil plantation, generate substantial carbon emissions. This will obviously contradict the carbon reductions represented by the use of waste from palm oil production in renewable energy projects. While the EU-Malaysia Biomass Sustainable Production Initiative (Biomass- SP) claims that there are investors from a different countries including Germany, France, Ireland, the UK, Korea, Thailand and Hong Kong who want to sponsor biomass projects, thus far there has been little interest from Malaysian palm oil millers.

Malaysian Palm Oil Council chief executive officer Tan Sri Yusof Basiron believes that palm oil millers would be interested in partnering with foreign investors, but have not yet heard about these opportunities. However, Biomass-SP technical adviser Datuk Leong Kin Mun reportedly told the Business Times that palm oil millers are afraid that such investment would disrupt the daily running of their plants, and so see it as risky. Leong also believes that many palm oil millers are simply not interested in renewable energy. "At the current rate of 21sen/kWh (7 US cents/kWh) TNB is buying renewable energy, the potential of electricity sales is worth RM394.8 million (US\$XX million). Upon implementation of the feed-in tariff 
system, the higher renewable energy purchase price could be an added incentive for palm oil millers to convert their POME biogas to electricity,” Leong apparently said.

\subsection{The Future for Renewables}

Malaysia adopted an Advanced Renewable Tariffs system and further renewable energy targets in April 2011. On 28 April, a Renewable Energy bill (RE Bill) and a Bill for Sustainable Development Authority (SEDA Bill) were passed by the House of Representatives. Moreover, a one percent feed-in tariff (FiT) will be paid to a renewable energy fund as REW goes to press in September 2011. Biomass, biogas, mini-hydropower and solar energy biomass are the current eligible resources for the FiT program. In addition to that, the target of RE in the energy mix consist of 985 MW or 5.5\% of generation mix by 2012 (Noruddin, 2011). The Malaysian tariff is followed by the successful policies worldwide. It varies by technology used and derives tariffs according to the production cost. It is obvious that the tariffs have been received enthusiastically.

Indeed, projects currently in the planning stages includes a move by EQ Solar Technology International Sdn Bhd, a subsidiary of China's Hangzhou Energy Solar Co. Ltd, which intends to manufacture solar modules, cells and wafers in Senai Hi-Tech Park in the southern state of Johor.

There some projects in Malaysia that is currently in the planning stages. For example, EQ Solar Technology International Sdn Bhd intends to manufacture solar modules, cells and wafers in Senai Hi-Tech Park in the southern state of Johor. This is a good initiative. It is planned to invest $\$ 500$ million in the project that will have a peak annual production of $50 \mathrm{MW}$ of modules, rising eventually to 200 MW (Noruddin, 2011).

Meanwhile, Berjaya Corp Bhd's (BCorp) plans to invest \$61 million in a 10-MW PV plant at Bukit Tagar, Selangor, on the west coast. Also in the pipeline there are some other projects including the Hulu Terengganu (250 MW) and Ulu Jelai (372 MW) hydro projects, a pilot 5-MW solar PV project in Putrajaya, and projects encompassing 51 biogas plants by plantation conglomerate Felda Holdings Bhd . These projects will use biomass waste including empty fruit bunches and palm oil mill effluent (Noruddin, 2011).

\section{Conclusion}

Usage of renewable energy resources has a significant impact on the natural flows of energy in the environment.

Efficient usage of resources makes the energy refillable. Malaysia is an agricultural country and it generates significant amount of agro-industrial waste that is a potential energy resource. The sunny weather of Malaysia throughout the year helps to make solar energy that is another potential energy resource. Moreover, the conversion system of wind energy in Malaysia is suitable for resort islands. High dependency on oil is reducing steadily in Malaysia by the replacement of other primary fuel (gas and fuel). The introduction of 5-Fuel Policy made the renewable energy (RE) as one of the main fuel for power generation. To date, the development of renewable energy has already been started in Peninsular Malaysia through 


\section{Macrothink}

Small Renewable Energy Program (SREP). It was established on the basis of willing buyer and willing seller between TNB and the SREP developers through Renewable Energy Power Purchase Agreement (REPPA). Due to the lack of robust commercial mechanism to support renewable energy, the development is progressing slowly. However, the introduction of Feed in Tariff by the government in 2012 under the RE Act and Action Plan involves purchasing power from RE developers at premium price. The development of RE is expected to increase with the introduction of this mechanism.

\section{Acknowledgements}

The research reported in this paper was fully supported by a research grant (UKM-DLP-2011-026).

\section{References}

Asma, I. W., Mahanim, S., Aulkafil, H., Othman, S., \& Mori, Y. (2010). Malaysian Oil Palm Biomass. Regional Workshop on UNEP/DTIE/IETC in collaboration with GEC, Osaka Japan.

Brohmann, B., Feenstra, Y., Heiskanen, E., Hodson, M., Mourik, R. Prasad, G., \& Raven, R. (2007). Factors influencing the societal acceptance of new, renewable and energy efficiency technologies: Meta-analysis of recent European projects, European Roundtable for Sustainable Consumption and Production, Basel, June 20-22 2007, [Online] Available http://www.erc.uct.ac.za/Research/publications/07Brohmann\%20et\%20al-\%20Meta-analysis. pdf.

Bush, S. R. (2006). Acceptance and suitability of renewable energy technologies in Lao PDR, Environmental Policy Group, Wageningen University, The Netherlands, Report for Asia Pro Eco Project TH/Asia Pro Eco/05 (101302).

Domac, J. Richards K., \& Risovic, S. (2005). Socio-economic drivers in implementing bioenergy projects, Biomass and Bioenergy, 28, 97-106. http://dx.doi.org/10.1016/j.biombioe.2004.08.002

GEF, Global Environment Facility (2007) [Online] Available: http://www.gefweb.org/interior.aspx?id=232\&ekmensel=c580fa7b_48_126_btnlink [2008, March 29]

Haw, L. C., Salleh, E., \& Jones, P. (2006). Renewable Energy Policy and Initiatives in Malaysia, International Journal on Sustainable Tropical Design Research \& Practice, 1(1), 33-40.

Islam, M. R. Saidur, R, Rahim, N. A., \& Solangi, K. H. (2009). Renewable Energy Research In Malaysia, Engineering e-Transaction, 4(2), 69-72.

Kementerian Tenaga Air Dan Komunikasi. (2005). The regional forum on sustainable energy, Marriot hotel Putrajaya, Malaysia, [Online] Available http://www.ktak.gov.my/print_details.asp?SpeechID=401. 


\section{Macrothink}

Environmental Management and Sustainable Development

ISSN 2164-7682

2013, Vol. 2, No. 1

Lorraine, E. (2004). The Global Politics of the Environment. (2nd Edition). Palgrave McMillan Publications.

Lucia, G., \& Debora, C. (2010). Renewable Energies, Relevant Social Groups and Actor Network, International Renewable Energy Congress, November 5-7 Sousse, Tunisia.

Mitchell, J. V., \& Schmidt, D. (2008). Resource Depletion, Dependence and Development: Malaysia, Chatham House, London.

Najib, M. (2009). Key note address: 14th Annual Asia Oil and Gas Conference, Kuala Lumpur, [Online], Avaliable http://www.pmo.gov.my/?menu=speech\&news_id=131\&page=1676\&speech_cat=2

Norma, V., \& Michael, F. (2004). Green Giants? Environmental Policies of the United States and the European Union. Massachusetts Institute of Technology (MIT).

Noruddin, K. (2011). Energy Policy Shift and Key Energy Projects Towards Sustainable Energy Future For Malaysia, $3^{\text {rd }}$ Energy Forum, Economic Planning Unit.

Othman, Z. A. (2005). The Future of Hydropower in Malaysia, water resources technical division, [Online] Available http://dspace.unimap.edu.my/dspace/bitstream/123456789/13823/1/The\%20Future\%20of\%2 0Hydropower\%20in\%20Malaysia.pdf.

Saidur, R. Rahim, N.A., Masjuki, H.H., Mekhilef, S., Ping, H.W., \& Jamaluddin, M.F. (2009). End-use energy analysis in the Malaysian industrial sector, Energy, 34, 153-158. http://dx.doi.org/10.1016/j.energy.2008.11.004

Shigeoka, H. (2010). Overview of International renewable energy policies and Comparison with Malaysia's domestic Policy, [Online], Available http://www.tradingeconomics.com/malaysia/gdp-growth-annual

UNDP (United Nations Development Programme) \& GEF (Global Environment Facility) 2004. Private sector partnerships with the undp-gef project 'Malaysia: Building integrated photovoltaic technology application project (mbipv).

Wright, P. D. (2008). Reconsidering public acceptance of renewable energy technologies: a critical review, Chapter for inclusion in: Jamasb T., Grubb, M., Pollitt, M. (Eds), Delivering a Low Carbon Electricity System: Technologies, Economics and Policy, Cambridge University Press.

\section{Copyright Disclaimer}

Copyright reserved by the author(s).

This article is an open-access article distributed under the terms and conditions of the Creative Commons Attribution license (http://creativecommons.org/licenses/by/3.0/). 